\title{
DIAGNOSTIC ASSESSMENT OF OCCUPATIONAL ASTHMA DUE TO PERSULFATE SALTS IN A PROFESSIONAL HAIRDRESSER - A CASE REPORT
}

Joanemile Pacheco Figueiredo, Fabiane Pomiecinski, Ariana Campos Yang, Fabio F.M. Castro, Jorge Kalil, Clovis E. S. Galvao

\section{INTRODUCTION}

Many different causative agents have been ascribed to occupational asthma (OA). Persulfate salts are low molecular weight chemical compounds widely used in different manufacturing processes, particularly in the cosmetics industry. Persulfate-induced asthma may represent $4 \%$ of all OA cases, ${ }^{1}$ and although the first cases due to persulfate salts were described approximately 30 years ago, ${ }^{2}$ the prevalence of the disease, its mechanisms, the risk factors for its development, the value of diagnostic tests, and the progression of these patients remain unknown.

We report the case of a hairdresser with respiratory symptoms associated with exposure to persulfate salts. The diagnosis of occupational asthma due to this compound was confirmed only by specific bronchial challenge test.

\section{CASE DESCRIPTION}

A 37 year-old hairdresser was referred to our occupational respiratory disease unit with a history of respiratory symptoms associated with her work environment. Five years ago, she started to work as a hairdresser and six months later, she started to complain of sneezing, running nose, nasal blockage, and ocular itching during work. At that time, she also complained of bilateral palpebral eczema. Three years after starting her job, she developed a work-related persistent cough with episodic wheezing that led her to look for emergency treatment on a number of occasions. When we examined the patient to confirm occupational asthma, she had not worked for a week and was asymptomatic. Skin prick testing to indoor allergens revealed no sensitizations. Total $\mathrm{IgE}$ was normal. The skin prick tests were also carried out with freshly produced $2 \%$

Division of Clinical Immunology and Allergy, Hospital das Clínicas, Faculdade de Medicina da Universidade de São Paulo - São Paulo/SP, Brazil. cdgalvao@usp.br and 5\% ammonium and potassium persulfate solutions, but no sensitization was detected. Patch testing showed sensitization to nickel sulfate $(++)$, Thimerosal $(++)$ and Colophonia (+++).

The patient had normal spirometry findings and the bronchial challenge with histamine revealed mild hyperresponsiveness in the airways (PC20 $3.90 \mathrm{mg} / \mathrm{ml}$ ). Bronchial challenge with potassium persulfate was carried out as described by Munoz et $\mathrm{al}^{3}$. The patient was admitted to the hospital for the duration of the test. On the first day, $150 \mathrm{~g}$ lactose (placebo) was tipped from one tray to another $30 \mathrm{~cm}$ away from the patient's face for $10 \mathrm{~min}$ utes in a challenge booth with independent air extraction. Pulmonary function was observed by measuring FEV1 and CVF at 10-min intervals for the first hour and at hourly intervals thereafter. No change was observed. On the second day, $5 \mathrm{~g}$ potassium persulfate were mixed with $150 \mathrm{~g}$ lactose and manipulated the same way as in the first day. After 60 minutes, the FEV1 decreased 23\% from baseline values, and the specific challenge test was considered positive. The patient was discharged 24 hours later with no complaints.

\section{DISCUSSION}

We have described a case of OA resulting from exposure to persulfate salts, which was confirmed by a specific inhalation challenge test. Several studies have supported the importance of specific inhalation challenges with persulfate to confirm the diagnosis, showing sensitivity of $100 \%$ and specificity of $87.5 \% .{ }^{4}$ The mechanism underlying the OA induced by persulfate salts remains unknown. Although there are some previous findings suggesting that asthma due persulfate could be an IgE-dependent reaction, immunological tests show a low specificity and sensitivity. ${ }^{3,5}$ In the present study, no specific IgE could be detected using the available standardized methods.

Some authors have already reported cutaneous and res- 
piratory symptoms occurring simultaneously in the same individual as well as reported evidence of cellular mechanisms mediated by $\mathrm{T}$ cells. ${ }^{6,7}$ The skin lesions in our patient appear to have been caused by other agents accord- ing to the sensitization revealed in the patch test.

In conclusion, until other tests provide more diagnostic accuracy, the diagnosis of OA resulting from persulfate exposure must be based on a specific bronchial challenge test.

\section{REFERENCES}

1. Kopferschmitt-Kubler MC, Ameille J, Popin E, Calastreng-Crinquand A, Vervloet D, Bayeux-Dunglas MC et al; Observatoire National de Asthmes Professionnels Group. Occupational sthma in France: a 1-yr report of the Observatoire National de Asthmes Professionnels Project. Eur Respir J. 2002;19:84-89.

2. Pepys J, Hutchcroft BJ, Breslin ABX. Asthma due to inhaled chemical agents-persulphate salts and henna in hairdressers. Clin Allergy. 1976; 6:399-404.

3. Munoz X, Cruz MJ, Orriols R, Bravo C, Espuga M, Morell F. Occupational asthma due to persulfate salts. Chest. 2003;123:2124-9.

4. Munoz X, Cruz MJ, Orriols R, Torres F, Espuga M, Morell F. Validation of specific inhalation challenge for the diagnosis of occupational asthma due to persulfate. Occup Med. 2004;61:861-6.
5. Aalto-Korte K, Mäkinen-Kiljunen S. Specific immunoglobulin E in patients with immediate persulfate hypersensitivity. Contact Dermatitis. 2003;49:22-5.

6. Perfetti L, Galdi E, Biale C, Garbelli N, Moscato G. Anaphylactoid reaction to patch testing with ammonium persulfate. Allergy. 2000;55:94-5.

7. Borelli S, Wüthrich B. Immediate and delayed hypersensitivity to ammonium persulfate. Allergy. 1999;54:893-4. 